\title{
Technology Transfer of Creative Industries in Riau
}

\author{
Zoel Hutabarat \\ Universitas Pelita Harapan \\ Tangerang, Indonesia \\ zoel.hutabarat@uph.edu
}

\begin{abstract}
Technology transfer activities are usually carried out by a large manufacturing company, but now the trend is starting to shift to the micro, small, and medium enterprises (SMEs), especially those in the creative field. Currently, there are no rules or national standard rules that could serve as guidelines for all the science and technology $R$ \& $D$ institutions and / or colleges for the orderly administration in the transfer of technology from the producer to the user. The fact is happening today is the implementation of the transfer of technology in Indonesia is still very low, both nationally and internationally. Rachmat Gobel said that so far the government has not sufficiently comprehensive policy to strengthen the depth of industry structure that will sustain the future development of national industry, including technology transfer and $R \& D$ (Andrian, 2008). Conditions that occur in Riau related to technology is the limitation experienced by the industry players; as one example is the clothing business. Production technology in Pekanbaru has not been able to support the development of this business. Employers choose to do production in Bandung, because according to them the quality of products derived from Bandung better, cheaper, and more sophisticated technology.
\end{abstract}

Keywords: Technology transfer, knowledge transfer, creative industries.

\section{INTRODUCTION}

Indonesia industrial system has evolved into a national and global order, the motion is highly dependent on the source of technology from other nations, especially countries that have advanced in technology and industrialized. Channels to acquire the necessary technology in industrialized mainly determined by the current technologies acquired through imports, either purchased directly, nor brought to the process of foreign investment. A high dependence on technology imports is one of the causes of the weaknesses of industrial systems and economic systems Indonesia (Umam, 2009).

This dependence can be reduced through the technology transfer process to the public. Lee and Win argued that technology is essential in the economic growth of a country, especially in developing countries (2004 in Umam, 2009).

\section{KNOWLEDGE TRANSFER}

Technology will benefit if understood and managed properly. This condition can be achieved through the selection of appropriate technology transfer. Some definitions regarding the transfer of technology can be seen in Table I.
TABLE I. DEFINITION

\begin{tabular}{|c|c|}
\hline Definition & Source \\
\hline $\begin{array}{l}\text { The process of transferring } \\
\text { scientific findings from one } \\
\text { organization to another } \\
\text { organization with the aim of } \\
\text { further development and } \\
\text { commercialization; typically } \\
\text { include the identification of new } \\
\text { technologies, protection of } \\
\text { technology through patents and } \\
\text { copyrights, and the establishment } \\
\text { of development } \\
\text { commercialization strategy. and }\end{array}$ & AUTM, n.d. \\
\hline $\begin{array}{l}\text { Commercial technology } \\
\text { dissemination processes that occur } \\
\text { in the form of technology transfer } \\
\text { transactions, which may or may } \\
\text { not be covered by a legally } \\
\text { binding contract (Blakeney, } \\
\text { 1989), but it involves } \\
\text { communication, from the assignor } \\
\text { to the recipient. }\end{array}$ & UNCTAD, 2001 \\
\hline $\begin{array}{l}\text { The challenge of connecting } \\
\text { technology innovation and the } \\
\text { transfer to the parties the priorities } \\
\text { and needs of the economy and } \\
\text { society in general. }\end{array}$ & $\begin{array}{l}\text { Centre for Skills } \\
\text { Development and Technology } \\
\text { Transfer-South Africa, n.d. } \\
\text { dalam CACCI, 2005 }\end{array}$ \\
\hline $\begin{array}{l}\text { The transfer of ideas, } \\
\text { information, methods, procedures, } \\
\text { techniques, tools, or technology } \\
\text { from the developer to the potential } \\
\text { users. }\end{array}$ & 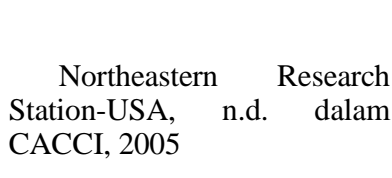 \\
\hline
\end{tabular}

Technology transfer can take place in a variety of ways, depending on the motivation and the resources available (Rogers et al., 2000; Lee \& Win 2004 in Umam 2009), namely:

- Interaction fellow researchers, conferences, and publications

- Consulting and mentoring

- The exchange program

- Cooperation program of research and development

- License

- Contract research

- Science park, research park and incubator (technology park) 
- Training

- Business first (start-up) or spin-off

The transfer of technology may occur if there is interaction and communication between stakeholders (academics, governments, and businesses and industries). The fact that happened on the field today are the result of research in science and technology (science and technology) is growing, but the utilization and utilization for users not as expected.

\section{REVIEW OF APPEAL}

\section{A. Singapore}

Together with Taiwan, Hong Kong, and South Korea, Singapore is one of the four economic tigers successful. Singapore's economic development model combines an open economy framework with strong state involvement in the sector through a policy of labor, land, and industrial development. Although this approach has allowed the country to move from the Third World into the First World, lately emerged a concern that the model of development needs to be improved by directing the economy to compete with developed countries in the field of technology.

Singapore entered a new phase of development, so that economic growth in the future will increasingly depend on its ability to create engines of domestic growth and the ability to engage in the creation of technology. Singapore traditional incentive policies to attract and support a multinational company did not attract young entrepreneurs, but to create dependency to multinational corporations in job creation and technology transfer, and inhibit the development of entrepreneurship and innovation. In the future, Singapore will be difficult to compete at the global level. Although the government has taken steps to cut labor costs and other costs, Singapore remains an expensive business location in Asia.

The Singapore Government has taken steps to stimulate entrepreneurship, especially in the high-tech sector. In addition to the regulatory and fiscal changes to make it easier to start a business, the government has set aside more than $\$ 1$ billion for venture capital and attract large venture capitalists establishing its Singapore office. At the same time, the government has also increased funding for university research and are aggressively wooing talented professionals to work in Singapore (Neidorf, 1999).

\section{1) Science and Technology Policy}

In the early years of independence, Singapore's strategy is attracting multinational companies. The heavy reliance on investment of multinational companies are part of the economic development strategy are more likely to make Singapore's position as a major business node in the system of global trade and capital flows (Wong, 2003). Strong efforts are consistently made to attract multinational corporations, investment in education and skills training, and encourage the diffusion of technology from multinational companies into the local economy. Granted tax incentives for manufacturing companies that conduct R \& D in Singapore.
Policy initiatives in the first five year plan of the National Technology, budgeted at SGD 2 billion, including acceleration in the development of technological infrastructure, boost R \& $\mathrm{D}$ to the private sector, and the development of technical personnel to support R\&D. Identified nine key areas to be developed are information technology and telecommunications; microelectronics and semiconductors, electronic systems; manufacturing technology; materials and chemical technology, environmental technology; energy, water, and resources; biotechnology; food and agro technology; and medical science.

Some new policy initiatives announced in 1998, including a master plan to improve skills and attract foreign talent, and Technopreneurship 21 (T21) business primarily in the field of high-tech technology. Program T21 represent changes in government policy which previously focused on technology adoption into diffusion and technological innovation. T21 initiative led to the liberalization in the regulations that restrain business considered first. In the late 1990s, Singapore redouble efforts to broaden and deepen the innovative capability and promote ongoing efforts in the creation of technology.

In 2001-2002, the Singapore government conducts a review of the country's economy. The final report by the Economic Review Committee (ERC) filed in late 2002, specifically identified six areas that require policy that Singapore's economy is more conducive to the development of entrepreneurship:

- culture: to influence the cultural values of the citizens of Singapore to entrepreneurship by providing more opportunities for students and professionals to learn about entrepreneurship;

- establish the capability: to attract more entrepreneurial talent from abroad and encourage greater mobility to the talent on the public and private sectors;

- the condition: to reduce government regulation and review the role of company associated with the government on the domestic economy;

- connectivity: to improve the global connectivity of Singapore to the world;

- capital: to improve business access to capital origin and SMEs; and

- The role of government (catalyst): to expand investment and tax incentives to multinational corporations and smaller companies.

\section{B. Thailand}

The key success factors of the transfer of technology is a collaboration between the government, universities, and industry. They have to work hand in hand. In the past it was not possible to combine the above three parties in a partnership. Less government support the private sector. The private sector in Thailand is not too strong. Most of them are small and medium enterprises (SMEs), which requires technology that is very small and low. Some medium and large companies sometimes require technologies from universities. However, as 
always universities have always complained that faculty cannot deliver the results on time. As a result, the private sector prefer to import foreign technology, a simple, no-risk, and timely.

Intellectual property system in Thailand is also increasingly important. Mission of the Department of Intellectual Property (DIP) are: 1) comprehensive development of an efficient system for protecting intellectual property, 2) promotion of the creation and commercial exploitation of intellectual property, and 3) preventing and combating violations of intellectual property rights and supervision of the use of intellectual property.

\section{1) Barriers to Technology Transfer}

\section{a) Domestic barriers}

Some domestic barriers to potentially disrupt the process of technology transfer to Thailand is the economic crisis and the lack of information networks. The economic crisis led the government to give priority to economic recovery. Most of the budget is allocated to public institutions which sometimes hinder development. Other barriers that hinder technology transfer process to Thailand are the technical and financial information is not adequate. Technology transfer can occur if there is awareness of the need to constantly update and disseminate technical and financial information to relevant agencies and the public. Regular information and the latest require adequate human resources, good information systems, and strong international support.

\section{b) External barriers}

External barriers are factors that could affect the success of the technology transfer process, due to the latest technology and the latest in the hands of suppliers. Unless the conditions are clearly defined, there is the possibility that transferred technology is outdated and does not deserve to host countries. Recipient countries like Thailand should be given sufficient information and experience at the international level to choose technology that is appropriate for the condition of the country, socio - economic and cultural development. In addition to the resistance of the exporting countries of technology, the development of this system has the potential to impede the transfer itself. The role of the private sector is believed to be important for the realization of an effective technology transfer activities. It is hard to imagine the high cost of technology transfer bias ahead without the support of public policy.

\section{TECHNOLOGY TRANSFER POLICY IN INDONESIA}

The Government of the Republic of Indonesia considers that technology transfer is one thing that is important for national progress, so the government issued Government Regulation (PP) No. 20/2005 which includes:

- Ownership of intellectual property rights as well as the results of research and development activities financed by the government, local government, or partly financed by other parties.

- How or mechanisms that can be done in the technology transfer of intellectual property and the results of R \& D activities include licensing, collaboration, services science and technology (science), and/or publications.
- The use of income derived from intellectual property and technology transfer results of research and development activities by universities and $R$ \& $D$ institutions for self-development.

PP No. 20/2005 it issued to implement the provisions of article 16 of Law (UU) No. 18 of 2002 on the National System of Research, Development and Application of Science and Technology; which requires colleges and R \& D institutions to commercialize the technology transfer of intellectual property, including the results of research and development activities to businesses, government, and society (Aard, n.d.).

\section{A. Conditions and Implementation of Technology Transfer}

The fact is happening today is the implementation of the transfer of technology in Indonesia is still very low, both nationally and internationally. Deputy Chairman of the Chamber of Commerce and Industry (Kadin) Indonesia Industry, Technology, and Marine-Rachmat Gobel-say, that so far the government's policy is not comprehensive enough to strengthen the depth of industry structure that will support the development of national industry in the future, including the transfer of technology and R \& D (Andrian, 2008)

Riau Conditions that occur in Riau related to technology is the limitation experienced by the industry players; as one example is the clothing business. Production technology in Pekanbaru has not been able to support the development of this business. Employers choose to do production in Bandung, because according to them the quality of products derived from Bandung better, cheaper, and more sophisticated technology (RiauBisnis.com, 2011).

\section{B. Creative industry Policy}

Some of the policies issued by the government in order to develop creative industries included in the book "Development of Creative Economy Indonesia 2025" (Ministry of Trade, 2008):

- Chapter VI, Article 17 of Law No. 5 Year 1984 regarding Industry said that industrial design protection law.

- Law No. 31 of 2000 on the Protection of Industrial Design Intellectual Property Rights.

- Decree of the Minister of Industry and Trade No. 20/MPP/ Kep/I/2001 on the Establishment of the National Design Council/National Design Center (PDN).

Governments have seen, that the creative industries contribute to the average value added amounted to $7.74 \%$ and the contribution of employment amounted to $7.76 \%$ during 2002-2010 (Simarmata \& Simarmata, 2011), and give attention to the industry. As part of its support for the creative industries, was issued Presidential Instruction No. 6 of 2009 on Economic Development Based Creative Industries. For further support, Trade Minister Mari Elka Pangestu (on tahun2009) said it would make the regulations that support creative industries that aims to help creative businesses in terms of production, 
marketing, to an understanding of the rules of trade (Inilah.com, 2009).

Various cooperation with other countries is done in order to strengthen Indonesia's creative industries, one of which is the signing of bilateral cooperation between Indonesia and the UK. Such cooperation in the form of exchange of information and knowledge, capacity building (capacity building), training, research, and showcase. The collaboration is focused on a subsector of music, movies, fashion, architecture, craft, design, animation, interactive games, digital, and culinary (Tanggapnews.com, 2012).

The local government also plays a role as well as supporting the development of creative industries. Research and Development Agency (BPP) and the Local Government (LG) Riau is the executor of this development. Some of these efforts, includes the development of young generation; bridge business capital owners or by third parties of capital by private parties or businesses; supervision, empowerment, and mentoring entrepreneurs. This activity is carried out with the aim of businesses will experience a significant advance, so as to accelerate the achievement of economic prosperity and increase awareness of IPR among creative industries (RiauBisnis.com, 2012). Other business conducted by The Government to promote the creative industries is to initiate the organization of exhibitions like Expo Riau, Pekanbaru Expo and MICE activities-meetings, incentive, convention, exhibition (RiauBisnis, 2010).

Relationship between Technology Transfer and the Creative Industries According to Richard Florida, the technology serves to accelerate, improve quality, and simplify business activities and social skills. Technology support productivity, so that it can be said that the ease of access and buy technology, and technology transfer is an important factor in the development of creative economy. The Indonesian government is very aware of the importance of technology transfer activities.

"Now Korea become a producer of creative industries. Government and private sector work together to develop this sector. They are now looking for a more competitive market. We would like to welcome him to the benefit of technology transfer to develop the creative industries. "Mari Elka Pangestu-Minister of Tourism and Creative Economy (Hidayat, A.R., 2012).

In a provincial scale, technology transfer policy in the creative industries sector is felt more and more important. As one example, the Provincial Government (Provincial) of East Java established a working group (WG) creative industries to strengthen the presence of creative industries in this area. Provincial government has made a medium-term work program for the period 2012-2014, which focuses on strengthening the domestic market, the guarantee of a conducive business climate, product certification creative industries, and accelerating the transfer of technology (MediaIndonesia.com, 2011).

In "The Global Competitiveness Report 2011-2012" was declared, that the index of economic creativity supported by a new venture index and index-technology consists of technological innovation and technology transfer index (Schwab, 2012). This situation shows that the presence and the effective transfer of technology was one factor that could increase the creativity of the national economy. One way to excel in the creative industry is the use of technology, innovation, and creativity. In real terms, creative industries cannot work alone to create excellence. They need the help of academics, governments, and businesses that have developed and established. Academics play an important role to contribute to knowledge transfer and research, and to transfer technology to businesses (Murniati, 2009).

Although technological innovation has contributed greatly to the economic activities in Indonesia, a great industrialization of technology transfer is not a lot is created. Ongoing technology development have a greater tendency to produce operators that depend on technology rather than produce innovators who are able to create technology after passing through the correct process of technology transfer. Research conducted by Djuitaningsih and Susanto (2010) showed that the majority of SMEs in Indonesia are not able to make stuff that really competitive and have not been able to create alternative technologies. This condition occurs because the technology transfer process to be not yet become the need of SMEs.

\section{CONCLUSION AND RECOMMENDATION}

- The heavy reliance on imported technology is one of the causes of the weaknesses of industrial systems and economic systems Indonesia.

- This dependence can be reduced through the technology transfer process to the public.

- Trends in the transfer of technology, which was previously a form of foreign investment and foreign aid, has been shifted to the transfer of technology in the national and regional levels, and also between institutions.

- The process of technology transfer can run well through cooperation between academia, government, and businesses

Policies and incentives are issued and managed by the local government to develop technology transfer in the scale area The policy with regard to human resources, through cooperation with schools and colleges new courses, curriculum charged creative industries) - Concrete R \& D cooperation between academia, government, and businesses - Development of information centers for businesses.

\section{REFERENCES}

[1] Koh, W.T.H. \& P.K. Wong, (2005), "Competing at the Frontier: The Changing Role of Technology Policy in Singapore's Economic Strategy", Technological Forecasting \& Social Change 72: 255-285

[2] http://portal.jnu.edu.cn/publish/uploadFile/2970/eWebEditor/201007010 65643139.pdf.

[3] PT. LETMI, CIEL SBM-ITB, \& BAPPEDA Jawa Barat, (2010), "Kebijakan Pengembangan Teknologi Tepat Guna untuk Pengembangan Industri Kreatif di Jawa Barat", K. Elissa, "Title of paper if known," unpublished. 
[4] Andrian, 2008, "RI Harus Manfaatkan Alih Teknologi", Diakses pada 28 November 2012 dari http://www.suarakaryaonline.com/news.html?id=212919.

[5] Association of University Technology Managers (AUTM), n.d., "About Technology Transfer", Diakses pada 10 Oktober 2012 dari http://www.autm.net/Tech_Transfer.htm.

[6] Badan Litbang Pertanian, n.d., "PP No. 20 Tahun 2005", Diakses pada 28 November 2012 dari http://www.litbang.deptan.go.id/regulasi/one/2/.

[7] CACCI, (2005), "Technology transfer Definitions", CACCI Journal 2, Diperoleh pada $10 \quad$ Oktober 2012 dari http://unctad.org/en/docs/psiteiitd28.en.pdf.

[8] Departemen Perdagangan RI, 2008, Pengembangan Eknomi Kreatif Indonesia 2025.

[9] Djuitaningsih \& Susanto, 2010, "Model Pembiayaan Usaha Mikro Kecil Menengah Produk Inovatif", Universitas Bakrie.

[10] Hidayat, A.R., 2012, "Indonesia Ingin Belajar dari Korea", Diakses pada $28 \quad$ November 2012 dari http://internasional.kompas.com/read/2012/09/23/11135853/Indonesia.In gin.Belajar.dari.Korea.

[11] Inilah.com, 2009, "Pemerintah Siapkan Regulasi Dukung Industri Kreatif", Diakses pada 28 November 2012 dari http://www.inilah.com/read/detail/176589/URLKARIKATUR.

[12] MediaIndonesia.com, 2011, "Jatim Bentuk Pokja Industri Kreatif", Diakses pada $28 \quad$ Oktober 2012 dari http://www.mediaindonesia.com/read/2011/05/05/225088/289/101/Jatim -Bentuk-Pokja-Industri-Kreatif.

[13] Murniati, D.E., 2009, "Peran Perguruan Tinggi dalam Triple Helix sebagai Upaya Pengembangan Industri Kreatif", dalam Prosiding Seminar Nasional Program Studi Teknik Busana.

[14] PT. LETMI, CIEL SBM-ITB, \& BAPPEDA Jawa Barat, (2010), "Kebijakan Pengembangan Teknologi Tepat Guna untuk Pengembangan Industri Kreatif di Jawa Barat", Tidak Dipublikasikan.

[15] RiauBisnis.com, 2012, "BPP Riau Dorong Lahirnya Industri Kreatif di Riau", Diakses pada 28 November 2012 dari http://riaubisnis.com/index.php/industry-news/kreatif-industry/4849bpp-riau-dorong-lahirnya-industri-kreatif-di-riau.
[16] RiauBisnis.com, 2011, "Clothing Pekanbaru Diproduksi di Bandung", Diakses pada 28 November 2012 dar http://riaubisnis.com/index.php/industry-news/kreatif-industry/2799clothing-pekanbaru-diproduksi-di-bandung.

[17] RiauBisnis, 2010, "Asperapi Riau: Pemda Masih Kuasai Market Share Industri Pameran di Riau", Diakses pada 28 November 2012 dari http://riaubisnis.com/index.php/industry-news/kreatif-industry/1851asperapi-riau-pemda-masih-kuasai-market-share-industri-pameran-diriau.

[18] Simarmata, E. \& B. Simarmata, 2011, "Bagaimana Posisi Strategis Industri Kreatif dalam Perekonomian Nasional?", Diakses pada 28 Oktober 2012 http://www.indonesiakreatif.net/index.php/id/news/read/bagaimanaposisi-strategis-industri-kreatif-dalam-perekonomian-nasional.

[19] Schwab, K., (Ed.), 2012, "The Global Competitivenes Report 20112012", World Economic Forum, Diperoleh pada 28 November 2012 dari http://www3.weforum.org/docs/WEF_GCR_Report_2011-12.pdf.

[20] Tanggapnews.com, 2012, "Indonesia Sepakati Kerja Sama Bidang Industri Kreatif dengan Inggris”, Diakses pada 28 November 2012 dari http://tanggapnews.com/2012/11/01/indonesia-sepakati-kerja-samabidang-industri-kreatif-dengan-inggris/.

[21] Umam, K.K., (2009), "Sistem Transfer Teknologi Universitas-Industri Studi Kasus di Institut Teknologi Bandung”, Program MSM ITB, Tidak Dipublikasikan.

[22] United Nations Conference on Trade and Development (UNCTAD), (2001), "Transfer of Technology: UNCTAD Series on Issues in International Investment Agreements", Diperoleh pada 10 Oktober 2012 dari http://unctad.org/en/docs/psiteiitd28.en.pdf.

[23] R. Nicole, "Title of paper with only first word capitalized," J. Name Stand. Abbrev., in press.

[24] Y. Yorozu, M. Hirano, K. Oka, and Y. Tagawa, "Electron spectroscopy studies on magneto-optical media and plastic substrate interface," IEEE Transl. J. Magn. Japan, vol. 2, pp. 740-741, August 1987 [Digests 9th Annual Conf. Magnetics Japan, p. 301, 1982].

[25] M. Young, The Technical Writer's Handbook. Mill Valley, CA: University Science, 1989. 